\title{
Between the King and the Sultan: the Romanian Colony in Constantinople at the End of the $19^{\text {th }}$ Century
}

The article focuses on certain results of a long-term research project which addresses a very specific aspect concerning Romanian-Ottoman relations after 1878: Romanian subjects, residents of the Ottoman Empire, perceived as a community under the protection of the diplomatic and consular missions of Romania. The present contribution accords particular attention to the definition of this community and the legal status of the members of the colony registered with Romanian consulates in the imperial capital. A brief discussion of their ethno-religious profile and socio-economic characteristics is also included in the analysis. This is the first attempt to analyse several aspects concerning the Romanian multiethnic colony in Constantinople from different perspectives, such as occupations, nationality papers or the major problems which influenced their status as foreign residents in the Ottoman Empire. The primary sources of data are the consular registers and correspondence between representatives of the Romanian state and the Ministry of the Foreign Affairs, with a special focus on the analysis of an unpublished volume of documents, no. 422, "Registration," and dated 1867-1916, from the Romanian Diplomatic Archives, Constantinople fonds. Other alternative sources were also used, such as censuses, newspapers and memoirs, in order to reconstruct an image of the Romanian colony in Constantinople up to 1900.

The history of an official Romanian community in the Ottoman Empire, protected by an independent state, has its beginning in the autumn of 1878, after the arrival and recognition of the first official Romanian diplomatic representative to the Porte, minister plenipotentiary Dimitrie Bratianu, who opened diplomatic relations between Romania and the Ottoman Empire. According to Article 50 of the Treaty of Berlin, from that moment onward, Romanian residents in the Empire were, at least in theory, under the protection of a foreign authority. This major change in their status came after centuries of assimilation as protected subjects of the sultan, nevertheless included in the main group of Ottoman subjects, since the provinces of Wallachia and Moldavia - after 1859 recognized as the United Principalities of Wallachia and Moldavia - were vassal principalities of the empire. For various reasons, Romania and the Ottoman Empire only signed a consular convention in 1918, which was of direct interest to the Romanian community in the Ottoman Empire, stipulating its status and rights. For four decades, between 
1878 and 1918, the status of these Romanian subjects was governed by the existing model of other foreign colonies in the empire, which was recognized by the capitulations signed with European states.

\section{Romania and the Ottoman Empire at the end of $19^{\text {th }}$ century}

The Treaty of Berlin of July 1878, which ended the Russian-Turkish War, was a major shift in the modern history of Romania. Recognition of its independence, a process which had begun through diplomatic channels from 1859 onward, prompted Prince Charles (1866-1916), the future King Charles I as of 1881, to reassess relations with the former suzerain, the Ottoman Empire. However, during his entire reign, Prince Charles paid only one official visit to Constantinople, in October 1866. He was received by sultan Abdülaziz at Dolmabahçe Palace and the result of the visit was the diploma of investiture (berat), which recognized his position as ruler of the United Principalities. In subsequent decades, Prince Charles followed the development of relations between the two countries with great interest. ${ }^{1}$ After the official establishment of diplomatic relations, Romania opened its Legation in Constantinople, followed by consulates in several cities where this was necessitated by economic, cultural or political interests: Salonica (Thessaloniki), Manastir (Bitola), Ianina (Ioannina) and Smyrna (Izmir). There were also small registered colonies of Romanian subjects in these regions, which was a further reason for a consular presence. ${ }^{2}$

After the Ottoman diplomatic and consular missions were established in Romania as well, the next step was the negotiation of different conventions in order to facilitate activities on both sides. Thus, in the four decades following independence, Romania signed, renewed or only negotiated different conventions with its former suzerain ${ }^{3}$ : a convention for the repatriation of prisoners of war (December $1878)$, a trade treaty $(1887,1897,1901,1907)$ and a consular agreement which was postponed several times for different reasons. The last was signed as late as $1918,{ }^{4}$ after several meetings took place and different versions of projects were drafted but failed to be finalized $(1886,1906,1907)$. The main reasons for this failure were the Romanian state's resistance to paying compensations to the Ottoman state for the landed estates in recently annexed Dobrudja, as well as the existence of a convenient system of capitulations, which resolved both the situation of Romanian diplomats and the Romanian colony in the Ottoman Empire.

\footnotetext{
For more details on his major role in the foreign policy of Romania, see DAMEAN 2011: 5992, DAMEAN 2017: 230-305, GIURESCU, DINU \& CONSTANTINIU 2010: 63-190.

2 For more details, see RACHIERU 2013: 125-139.

3 For a detailed analysis of the conventions, see RACHIERU 2018: 143-168.

4 For the text of the convention, see KUNERALP 2000: 445-457.
} 
Another problem in consular activity was the lack of an extradition convention between the two states. Therefore, no action could have been taken by the authorities in cases like the one of Fizel Swartz Assouratitch, who, accused of fraudulent bankruptcy by the Romanian state, managed to escape to Smyrna without any punishment. ${ }^{5}$ Thus, the decades up to World War I were marked by these legal ambiguities, which strongly influenced the status of Romanian subjects in the Ottoman Empire, as discussed below.

\section{Romanians as foreign subjects in the Ottoman Empire}

The 1918 Consular Convention between Romania and the Ottoman Empire stipulated, in Article 13, that "the consuls general, consuls and vice-consuls or those who replace them are authorized to protect the rights and interests of the subjects of their country and, moreover, to protect and encourage the trade activities of these subjects." ${ }^{\prime 6}$ This consular duty was mentioned as such in all previous drafts of conventions but, as stated before, it was only officially adopted in 1918.

After state independence in 1878, Romanian subjects entered the same system of protection as other subjects of the European states which received capitulations from the Ottoman state. Thus, according to the Capitulation of 1740 granted to France, which was extended in fact to encompass all foreign subjects in the Empire, and its revision of 1867 which offered the possibility of acquiring real estate, foreign subjects enjoyed the right to be legally protected by consular tribunals, to have their commercial activity supported by the consulates, to be married and divorced in their consulates, etc. ${ }^{7}$ Several additional stipulations were imposed by the Nationality Law of 1869 as well, especially concerning the renunciation of Ottoman nationality. According to this new law, "all persons domiciled in Ottoman territory were to be considered Ottoman subjects, unless they could prove the contrary and, further, that no Ottoman subject might become a citizen of another state without the preliminary consent of the Porte. ${ }^{\prime 8}$ In the summer of the 1869 , three more amendments were added: first a commission whose role was to analyse the status of presumptive Ottoman subjects requesting foreign protection was established; the other two amendments dictated more strict control of passports for both Ottoman and foreign subjects. As previously mentioned, the status enjoyed by Romanian nationals in the Empire existed in theory. On the

5 Başbakanlık Osmanlı Arşivi (hereafter BOA), HR.H. 563/4/1, verbal note, Ottoman Minister of Foreign Affairs Constantinople to Royal Legation of Romania, 6 July 1892.

6 KUNERALP 2000: 448.

7 For a detailed analysis of the status of foreigners in the Ottoman Empire, see BROWN 1914.

8 DAVISON 1963: 263. A detailed analysis of the impact of 1869 Nationality Law is available OSMANAĞAOĞLU 2004: 173-250. 
contrary, many ambiguities were determined in practice by their previous status of protected subjects of the Sultan, as emphasized in the subsequent paragraphs.

On 4/16 December 1878, local journals like Constantinople or La Turquie published the following official notification in Romanian, French and Greek: "All Romanian subjects, residents in Constantinople and its suburbs, are invited to come to the Romanian consulate without any delay, with all the necessary papers, in order to be registered." "It was the first publicly-announced attempt by the recently opened Romanian Consulate General to identify and create a database of subjects in the Ottoman Empire. Previously, some lists were created in 1870 and 1872 only at the request of the Romanian Ministry of Foreign Affairs. Those residents who registered with the Diplomatic Agency were granted specific certificates which recognized them as subjects of the United Principalities of Walachia and Moldavia, as discussed below. ${ }^{10}$

Another clarification of the terms is necessary. The term Romanian citizen is not used in the entire article due to the specific juridical situation of the time in Romania. Before 1878, so-called religious-restricted citizenship existed in Romania. The Constitution of 1866, Article 7, denied non-Christian foreigners access to Romanian citizenship: "Only foreigners of Christian rite may acquire naturalization." 11 The Treaty of Berlin of 1878 imposed that, in order to have its independence recognized by the Great European Powers, Romania had to grant civil and political rights and to admit in public service, functions and honours all of its subjects, irrespective of their religious belief or confession; to guarantee the liberty of practice and organization of religious cults to all of its inhabitants; and to equally treat all foreign citizens in Romania regardless of their religion (Art. 44), which could have ended the legal discrimination of the Jews and at the same time instituted an inclusive policy for the Muslims from Dobruja. This was nonetheless not the case in the new state: as historian Constantin Iordachi points out, "Romanian political elites successfully avoided the strict application of the Treaty of Berlin."12 The amendment to Article 7 stipulated only individual access to naturalization for non-Christian residents under restrictive conditions, after ten years spent in the country. At the same time, inhabitants from Dobruja received local citizenship, after the special law for Dobrudja was issued in 1880. They had no political rights or the right to acquire real estate at the national level, only in the territory of Dobruja, which explains the notion of "local citizens" Iordachi uses in his study.

\footnotetext{
9 Arhiva Ministerului Afacerilor Externe (hereafter AMAE), Constantinople fonds, folder 422, journal pages.

10 AMAE, Constantinople fonds, folder 422, 14/28 February 1870, Dimitrie A. Sturdza, Diplomatic Agency of United Principalities, Pera to Alexandru Golescu, Ministry of Foreign Affairs, Bucharest.

11 MURGESCU 2001: 208

12 IORDACHI 2002: 23.
} 
Thus, from the legal standpoint, it is preferable to use the term subject instead of citizen for the members of the Romanian colony in Constantinople, as many of them had been long-term residents in the imperial capital and did not clarify their status after 1878. The Romanian authorities also used it in their correspondence.

\section{"Real Romanian subject" - definition, nationality dilemmas and confusions}

The main research question of this specific case study is how to portray and identify a Romanian subject in the Ottoman Empire. In a century of national movements, in the decades of political emancipation of the Romanian Principalities, it was not an easy task to define the community and to impose its name onto the authorities of the country of residence, with whom a long and different history was shared. In a report from 1870, Dimitrie Sturdza, the Romanian diplomatic agent in Constantinople, used the term "Romanian subjects," which seemed the correct option for the Romanian authorities, but not for their Ottoman counterpart. Also, the residence permit mentioned the Diplomatic Agency of Romania as the authority (see fig. 1). In 1870, despite the diplomatic efforts of the Romanian diplomats or implicit acts of the sovereign, ${ }^{13}$ the suzerain power continually refused to recognize the name of the country as Romania and insisted that the decision on this aspect of the Paris Convention of 1859 should have been respected. ${ }^{14}$ After 1878 , the name was not a diplomatic subject anymore, as the Treaty of Berlin officially recognized the independence of the state called Romania. Consequently, if the name "Romanian subjects" designated the colony for officials in Bucharest, the Ottoman authorities referred to them only as subjects of the United Provinces or Principalities.

In a report written by the Diplomatic Agency in February 1870 quoted above, after a careful selection, a total of 50 people were registered. This selection led to the first definition of a Romanian subject in the Ottoman Empire which actually focuses on what was not a Romanian subject: "eliminating those who are native to Turkey, for whom the Romanian passport does not represent a title of naturalization, who were not leaving Turkish territory more than temporarily, those who do not have parents or interests in Romania, and they or their sons are in the service of the Sublime Porte," ${ }^{15}$ were consequently considered as Ottoman subjects. Their

13 The first article of the 1866 Constitution stated that: "The United Romanian Principalities constitute an indivisible state under the name Romania”, MURGESCU 2001: 208.

14 Interesting correspondence concerning the recognition of the name was exchanged in 1872 between the Ottoman Ministry of Foreign Affairs and the Ottoman embassies in Paris, Vienna, and London. The Sublime Porte insisted on "maintaining the nomination registered by time and treaties." BOA.HR.SFR.4.228/53.

15 AMAE, Constatninople fonds, folder 422, 14/28 February 1870, very confidential, Dimitrie A. Sturdza, Diplomatic Agency, Pera to Alexandre Golescu, president of the Council of Ministers, Minister of Foreign Affairs, Bucharest. 
names appeared on a list of "undeniable Romanian subjects" and resident permits were issued (fig. 1). The agent Dimitrie Sturdza explained as well that after this clarification "the protection which we are offering to real Romanian subjects [author's emphasis] will be more effective." Already a mixed legal situation may be noticed, as from the Romanian perspective they were subjects of the state, while from the Ottoman perspective only protected subjects of the sultan. In a report written in 1882, four years after independence, the Romanian consul general in Constantinople synthetized the situation as follows and thus formulated a second definition: "Until the recognition of the state's independence, Romanian subjects, meaning residents born in Romania and who did not enjoy foreign protection [author's emphasis], were accepted into the Empire as privileged subjects and, at the same time, enjoyed the protection of the Romanian mission here and were recorded in the registers of the Chancellery of the former Diplomatic Agency. Article 50 of the Treaty of Berlin changed this status of our subjects and made them equal to the subjects of the other European powers." ${ }^{16}$ The same diplomat summarized the problems in one phrase, considering that they appeared due to two aspects: the unclear definition of the notion "subject" and local habits from the Ottoman Empire, which is a synthetic interpretation of the discussions to follow.

A perfunctory examination of the 1870 list reveals the complexity of the situation from the ethno-religious perspectives as well, as the majority can be identified as Greeks, Jews or Armenians. A similar situation was apparent in 1872 as well, with an annotated list of 101 people, most of Greek or Jewish origin. The list includes age, father's name, place of residence and years of residence in the Ottoman capital, data which needs to be analysed in detail in a comparative perspective with the situation after 1878 in a future study. ${ }^{17}$ Just as a brief remark, on 19 June 1889, Raul Sturdza, the consul general in Constantinople, complained to his superiors that "the insufficiently Romanian character of our colony in Constantinople drew my attention once I arrived at this mission." 18 Sturdza promised a detailed review of the consular records by inviting every person on the list to the Consulate in order to clarify their status. Four years later, the same consul, while he was proceeding with a new census, still complained that "the great majority are in fact total foreigners, not speaking Romanian, not having any connection to our country, not even commercial, like the case of those who benefited from the $3^{\text {rd }}$ article of the 1880 Law for Dobrudja, only because they spent a certain amount of time in

16 AMAE, Constantinople fonds, folder 422.

17 AMAE, Constantinople fonds, folder 422, 14/28 February 1870, very confidential, from Dimitrie A. Sturdza, Diplomatic Agency, Pera to Alexandre Golescu, president of the Council of Ministers, Minister of Foreign Affairs, Bucharest.

18 AMAE, Constantinople fonds, folder 422, 19 June 1889, M. Stourdza, Consulate General to Al. Lahovary, Ministry of Foreign Affairs Bucharest. 


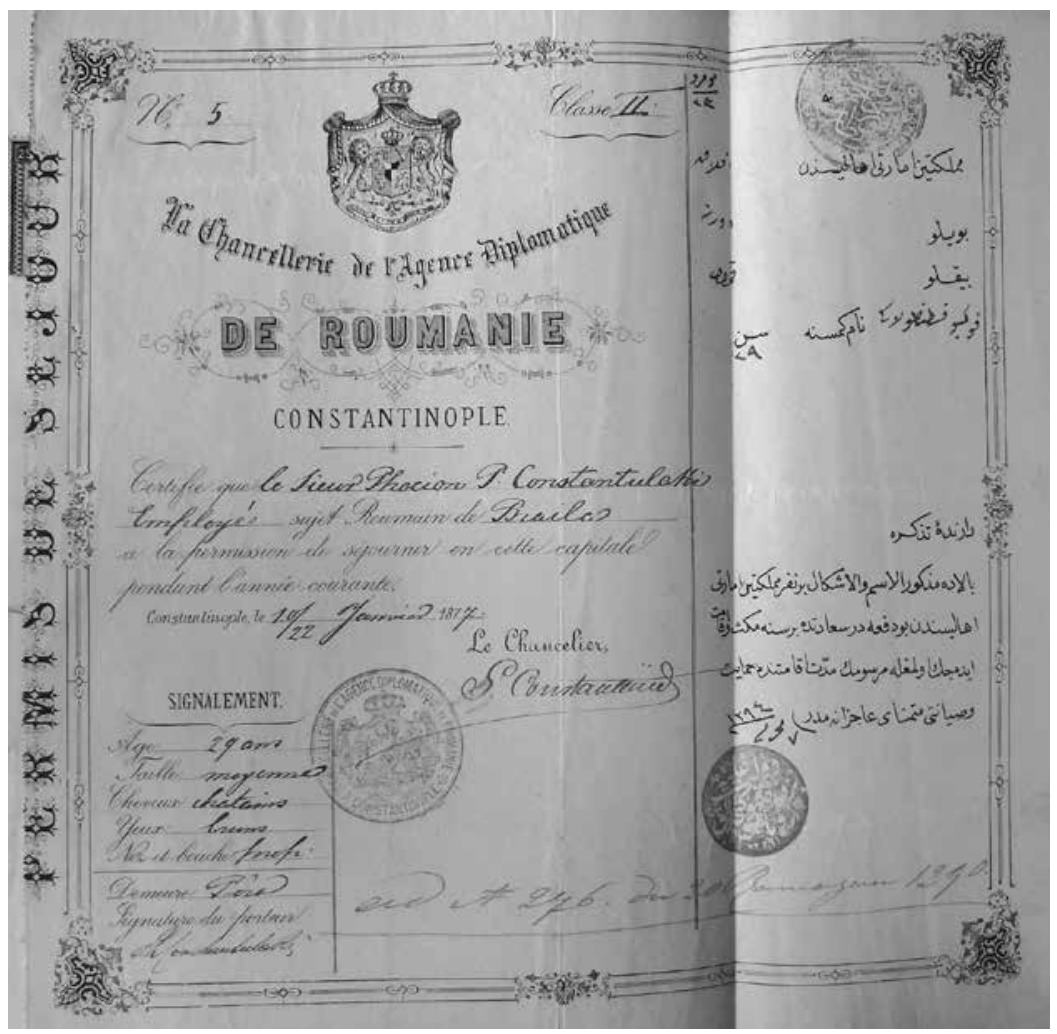

Fig. 1 Example of an annual residential permit (permis de séjour) issued by the Diplomatic Agency of Romania, 1877 (AMAE, fonds Constantinople, folder 422)

that province." 19 As a consequence, identifying "a real Romanian subject" was apparently not an easy task to accomplish for the consular staff.

The response to the announcement published in December 1878 is apparent in a collection of requests for registration written in Romanian, French or Greek (fig. 2), with detailed information about the subject: age, place of birth, place of residence, which also included in most cases the residence permit issued by the Diplomatic Agency of the United Principalities with all details about their physical appearance. The documents were archived in a separate file designated "Requests for Passports and Registration" which includes twenty examples. It should not be overlooked that the list includes only male subjects, as female subjects had no juridical recognition in Romania until the First World War, except for widows with children. Their number is possible to identify only when some details about the family of the subjects were mentioned, providing some partial results.

19 AMAE, Constantinople fonds, folder 422, $2 / 14$ February 1893, M. Stourdza, Consulate General to Ministry of Foreign Affairs Bucharest. 


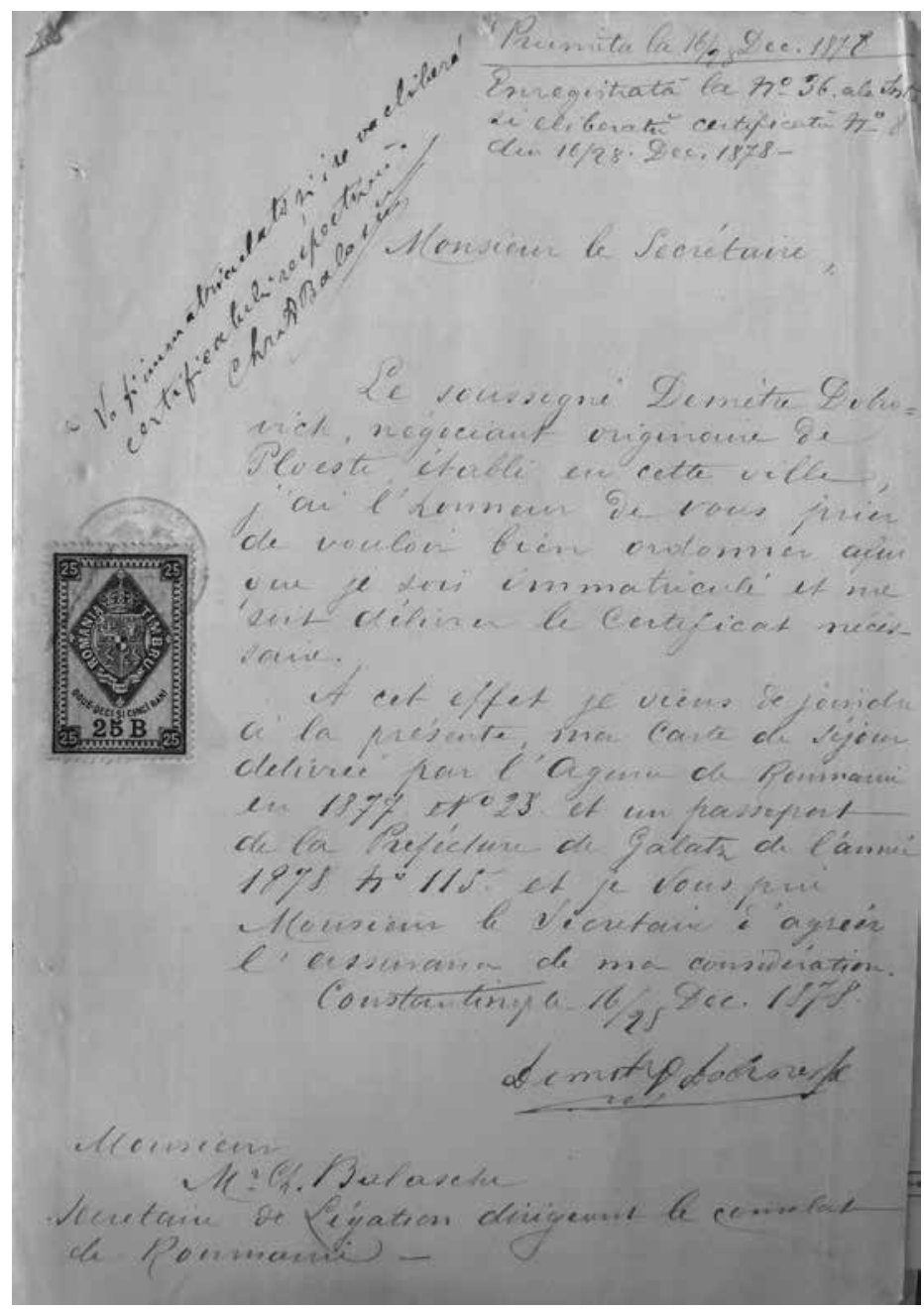

Fig. 2 Example of a request for registration of a Romanian subject to the Legation of Romania, December 1878 (AMAE, Constantinople fonds, folder 422)

In February 1881, the Ottoman authorities sent the Romanian Legation a new demand to provide a detailed list of Romanian subjects in the perspective of an Ottoman census. The response of the Consulate General, addressed to the Royal Legation, was that they did not have the capacity to furnish the exact number due to the lack of personnel and a clear delimitation of their area of control. ${ }^{20}$ The problems continued in 1882 when the local authorities issued a special request that, in order to avoid confusion, passports should also be validated by the Ot-

20 AMAE, Constantinople fonds, folder 422, 21 January 1881, Consulate General in Constantinople, Alexandru Farra, consul to Royal Legation, Dimitrie Bratianu, minister. 
toman authorities, as the 1869 Nationality Law stipulated. One example is the case of Jean Camiatzo, who was imprisoned because he did not pay the military tax/bedel-i askeriye, and his passport was contested, but in the end his Romanian nationality was accepted by the local authorities. It was not an isolated case, several examples are available, especially for the first decade after independence.

One solution to limit confusion was proposed in 1883 by the Romanian consul in Constantinople and was similar with those adopted by other legations: to issue a permanent residency card, which could have respected both local and international legislation. ${ }^{21}$ The solution was rejected by the Romanian Ministry of Foreign Affairs, which insisted on a detailed analysis of each case. In the end, the evidence every subject could present in his defence as well as an interview and a detailed analysis of each file were the ultimate solutions for proper registration in the consular registers. One example to support this idea is the case of Jean Seiniri, merchant resident of Constantinople who needed to be recognized by the Office of Nationalities of the Sublime Porte as a Romanian subject. In his defence, on 16 March 1885 the Romanian Legation requested that the Ottoman Ministry of the Interior to proceed thusly, mentioning that "the evidence which determined the nationality of the applicant is indisputable. Jean Seiniri, even if born in Constantinople, has parents originally from Romania, as written in the registers of the Chancellery of the Consulate General of Constantinople as well. His father, Alexander Seiniri, in his turn, has never stopped paying the usual taxes to the consular authorities and his name appears in an uninterrupted manner in the mentioned registers since 1844."22

One can assume that the long-term residence of several decades in the Ottoman Empire, underscored by the experience of changes of 1878, could have been perceived as a guarantee of the non-ambiguous legal status of Romanian subjects. In theory it might be accepted as a strong argument, but in practice the transition and assimilation of Romanian subjects as foreign subjects was not as smooth as one might think, as different cases demonstrate once again. On one side, the Ottoman authorities were trying to exploit the ambiguities to their advantage, while on the other Romanian diplomats were compiling long, argumentative reports each time a new case became an issue between the Bureau of Nationalities and the Royal Legation. For instance, minister plenipotentiary Trandafir Djuvara explained in a correspondence from 4 August 1899 addressed to Tevfik Pasha, the Ottoman Minister of Foreign Affairs, the specific situation of two brothers, Pierre and Jean Alexiu. ${ }^{23}$ The brothers, born

\footnotetext{
$21 \quad$ AMAE, Constantinople fonds, folder 422, 24/5 May 1882, confidential, Romanian Legation in Constantinople to Romanian Ministry of Foreign Affairs.

22 BOA.HRH.553/16. A similar situation is detailed for Zaharia Constantin, BOA.HRH.553/20 or other merchants detailed in the file BOA.HRH.553/25, from 1886.

23 BOA.HRH.563/10/19.
} 
in Galatz (Galați) had been residents of Mitilini since 1872 and complained to the Romanian Legation that their nationality was not recognized by the local authorities and they were obliged to pay the military tax, being assimilated as Ottoman subjects. The Romanian diplomat, in order to clarify the situation, wrote a detailed report insisting that upon their arrival in Mitilini in 1872 the two were registered as Wallachian subjects i.e. Ottoman subjects, but after 1878 they should have been perceived as foreign subjects, as specified by the Treaty of Berlin. Djuvara was aware of the fact that the two brothers were not registered in the documentation of either the Diplomatic Agency of Constantinople or the Legation, but he also mentioned it as a frequent situation for subjects who lived outside of the capital. Before 1878, Romania had only one diplomatic office in the Empire to which they could refer, in Constantinople, and sometimes it was too far from their homes.

Nevertheless, the Chamber of Legal Counsels of the Ottoman Ministry of Foreign Affairs rejected these explanations and claimed that: "the subjects in question have had their residence in Turkey since 1872, meaning before the independence of Romania. At that moment they were Ottoman subjects and they retained their nationality without any action which could suggest that they want to change their original nationality. Moreover, they have fulfilled all of the duties imposed upon nationals of the Empire at their own initiative. In any case, the Imperial Government cannot accept that the recognition of the independence of the United Provinces [author's emphasis] had as a consequence the transformation of Ottomans from the aforementioned provinces [author's emphasis] who settled in the Ottoman Empire years before independence into Romanians. ${ }^{24}$ One should not be surprised by the persistence of Ottoman jurists in referring to the United Principalities as the United Provinces, as in the Ottoman Constitution of 1876 they were still identified as Protected Provinces: memalik-i mahruse. The ambiguity continues in the legal report, mentioning that the Treaty of Berlin transformed only those who were residents of Romania in 1878 into Romanian subjects, while those who lived in other provinces of the empire were not entitled to the new independent nationality. It is noteworthy that this is a report written in March 1900, meaning that twenty-two years of independence had not proven sufficient to clarify their status. At the same time, it may be understood as a different, albeit somewhat forced, interpretation of Article 5 from the Nationality Law of 1869 , which stated that if a subject become a foreign subject without the consent of the Ottoman government, his naturalization was deemed null and void and he was considered an Ottoman subject. On the other side, the Romanian minister, Trandafir Djuvara, stressed in his report the fact that the Nationality Law of 1869 had no effect on the subjects of the United Principalities, due to their special status. As a conclusion, it seems that the legal framework had its limits and ultimately did not offer much

24 BOA.HRH.563/10/23. 
clarification on the situation of Romanian residents in the Ottoman Empire in the first decades after independence, and considerable confusion led to erroneous registrations, long debates over the status of a subject, or, as I used to call it in a different context, the "hunt for subjects" was not always beneficial to the people.

Being automatically considered an Ottoman subject prior to 1878 could have had some advantages too, as explained by jurists from the Chamber of Legal Counsels of the Sublime Porte: the Romanian subjects had no right to possess or acquire real estate in the Empire because Romania did not sign the 1867 protocol attached to the 1740 Capitulation granting the foreigners the right to hold real estate in the Ottoman Empire. Ottoman jurists mentioned that "it was acceptable to sell their property only to Romanian subjects who held real estate in Turkey in a period prior to the Treaty of Berlin because they acquired them in their capacity of Ottoman subjects." 25

In the documents consulted, another aspect constantly recurs: fraud. It was not an easy task to identify if somebody was a Romanian, Greek or Ottoman subject. Quite often residents in the imperial capital exploited this ambiguity and assumed one status or another according to their needs. There were different circumstances which influenced their decision to perpetrate fraud: military service, financial obligations, judicial problems, and sometimes familial matters such as divorce, polygamy, etc. In the case of Ottoman subjects, another reason was the difference in status between a resident foreigner in the empire and a local. One consul emphasized to his officials that the independence of Romania also made Romanian nationality also desirable for Ottoman subjects who wanted to avoid their domestic obligations: "I shall remind you that due to the fact that the Capitulations offered special privileges to foreign subjects and the exceptional power provided by the Sublime Porte to foreign powers, local consulates and the subjects under their protection benefit from an exceptional status which is in opposition to the poor status of the rayas (i.e. subjects, Ott. Tr. reaya) of the Sublime Porte, and protection became an object of desire by all Ottoman subjects." ${ }^{26}$ The same diplomat also stressed that even if each country wanted to expand its colony and reinforce its position in this way, registration at the consulate should be the result of detailed research for each case, in order to avoid confusion. ${ }^{27}$ Therefore, the

25 Report 506, Constantinople, 9 December 1890, Report 506, Gescher and Gabriel Effendi in Kuneralp \& Öktem 2012: 431.

26 AMAE, Constantinople fonds, folder 422, 20 May 1882, Consulate General in Constantinople, Alexandru Farra, consul to Royal Legation, Olanescu, charge d'affaires.

27 "It is true that each state has the greatest interest in having as large a colony as possible here, because a bigger, larger colony dictates greater rights, but I think this consideration should not be so powerful as to refrain from according any attention if the person who claims this favour really deserves it and satisfies all of the criteria of morality and origin." AMAE, Constantinople fonds, folder 422, 20 May 1882, Consulate General in Constantinople, Alexandru Farra, consul to Royal Legation, Olanescu, charge d'affaires. 
permanent interest of the Romanian authorities was to create a portrait of the Romanian subject in the Ottoman Empire, an interest which was particularly apparent each time the local authorities asked for lists of residents. In July 1882, a request with a three-month deadline was issued for complete data: name, surname, sex, age, profession, country of origin, place of birth and religion/confession, marital status - a request repeated in the two main periods of preparation of the census in the Ottoman Empire, 1883-1887 and 1888-1893.

In the following decades, the evaluation of the colony completed in 1883 was deemed by the consular staff as the first which should be taken into consideration. After all of the legal debates mentioned above, the criteria used by the Romanian consul, Alexandru Ecsarhu, to evaluate and register the colony were the following ${ }^{28}$ :

- those registered by the Diplomatic Agency prior to 1878 who met the various requirements imposed by the Romanian Ministry of Foreign Affairs

- those registered by the consulate between 1878 and 1883 who presented clear and correct documents to claim their nationality

- those Dobrudjans who presented evidence according to the 1880 Dobrudja Law.

All three categories of subjects were individually summoned to the Consulate with their papers for a new verification and interview. The result was a census of the Romanian colony from Constantinople dated 15/27 March 1883, which gives at the same time a picture of the previous situation. Before the new evidence was created, Consul Ecsarhu evaluated the status of a total of 179 subjects, after the elimination of four dead people, one person registered twice, 17 who had left Constantinople and eight who had renounced their nationality, as well as a detailed analysis of the archives of the consulate from 1844 onward. In order to attain a picture of the evolution of the community and the activity of the Consulate General, their chronological registration should also be mentioned:

- 13 between 1/13 December 1878 - 1/13 January 1879

- 57 between $1 / 13$ January $1879-1 / 13$ January 1880

- 38 between $1 / 13$ January 1880 - 1/13 January 1881

- 25 between $1 / 13$ January $1881-1 / 13$ January 1882

- 46 between 1/13 January 1882 - 1/13 January 1883 .

Ecsarhu also divided the total of 179 into three categories: 118 registered according to the pre- 1878 regulations and who held residence permits, ten Jews and 51 people with incomplete papers. Furthermore, he managed to identify another group of 49 people who were not registered before and put them into the same categories: 14 respecting pre-1878 regulations and holding residence permits; nine Jews; 26 with incomplete papers.

28 AMAE, Constantinople fonds, folder 422, 1 March 1883, Al. Ecsarhu, Consulate General to Petre Mavroieni, Royal Legation Pera. 
The detailed analysis of the archives permitted the consular agent to restore the criteria of recording in the consular registers which had to be used after 1883, pursuant to the revised Romanian Constitution and the 1880 Law of Organization of Dobrudja:

- Born of parents with Romanian citizenship.

- Naturalization or residence in Romania in order to receive the naturalization - reference to the religiously-restricted citizenship discussed above.

- For Dobrudjans - domicile in Dobrudja and renunciation of any foreign nationality. ${ }^{29}$

The new census conducted by the Consulate General in 1883 mentioned in the end a total of 113 people, which was not considered a definitive number as some of the previous registered subjects did not have the new individual verification completed, due to the lack of time to appear in person at the consulate or the necessity for additional papers. Ten years later, a new consular census was conducted, taking into consideration the result of the 1883 census and the registrations completed during the intervening decade, a total of 156 subjects. The result of the new investigation drastically reduced the number to 66 , a number which seemed to remain realistic for the next decade as well, in terms of official registration.

Out of the 66 subjects mentioned above, the consul general managed to create eight categories, in order to differentiate them, as follows:

- registered themselves or their parents with the former Diplomatic Agency 50 to 30 years ago -23

- under Romanian protection from 25 to 18 years ago - 3

- after naturalization - 1 (1886)

- by governmental order -15

- born in Romania and with the military service completed -6

- Dobrudjans with voter certificates -9

- employees of Romanian enterprises - 2

- $\quad$ workers identified only by passports -7

The fact that the numbers varied or even drastically diminished expresses, in my opinion, the difficulty in registering a colony.

\section{Socio-economic profile of the Romanian colony}

As in other cases of population analysis, it is no easy task to estimate the size of the Romanian colony in Constantinople, due to the complex factors emphasized in paragraphs above. As is common in our own day as well, some people preferred not to be listed in the consular registers and as a consequence the exact

29 AMAE, Constantinople fonds, folder 422, 17 February/1 March 1883, Petre Mavrogheni, Royal Legation, to Al. Ecsarhu, Consulate General. 
number of Romanian residents in the imperial capital is impossible to determine in the official documents issued by the consulates. According to Kemal Karpat, in Constantinople in 1899 the number of foreigners was 126,752 out of a total population of almost $900,000\left(873,565\right.$ in 1885) ${ }^{30}$ Historical colonies like the French, Italian, Austrian-Hungarian or more recent Greek predominated. Petre Mavrogheni, the Romanian minister plenipotentiary, even put forth numbers such as 10,000 for Italy, 14,000 for Greece or 7,000 for Austria-Hungary. ${ }^{31}$ Among them, the Romanian colony represented only a very small percentage, as in 1893 only 66 people were officially registered. ${ }^{32}$ Nevertheless, one should not forget that this number was not only limited, but also represented only adult males, as women and children did not appear in these lists compiled by the Romanian Consulate General. A general estimate could indicate approximately 1,000 members, as one takes into consideration also the students at Galatasaray Secondary School or other foreign schools, various Vlachs who received Romanian nationality, priests and last, but not least, outlaws. Moreover, according to Ottoman legislation, interpreters - dragomans and couriers/çavuş - could enjoy temporary foreign protection while they worked for a diplomatic mission, and employees of the Royal Legation were among the examples, some of them for decades. ${ }^{33}$

In order to identify the socio-economic profile of Romanian subjects, several sources may be used and compared at the same time: consular registers which still offer limited information, Romanian and Ottoman diplomatic archives - especially their collections with legal matters which include requests or distribution of judicial documents, appeals for identification of different persons with debts to the Ottoman treasury or of husbands who went back to work in Romania, the collection of Annuaire Oriental, etc. Many members of the colony chose Constantinople for commercial purposes. Reading the various documents, one can see merchants like Marco Fitterman, who lived in Camondo Han, teachers like Louise Ionesco, an employee of Chevket Bey (secretary at the Ministry of Finance), pharmacists like Demetre Belisaire, prostitutes like Madame Pauline who was accused of public disorder, or, as they were called by one consul in 1908, "a floating Romanian population of singers," journalists, etc. Once a Romanian business opened its branches in the Ottoman capital, more people were employed, such as the insurance company Dacia or the oil company As-

\footnotetext{
30 KARPAT 1985: 161.

31 AMAE, Constantinople fonds, folder 422, 18 December 1883, P. Mavrogheni, Royal Legation to D.A. Sturdza, Ministry of Foreign Affairs, Bucharest.

32 AMAE, Constantinople fonds, folder 422.

33 An example is the Levantine family Lahaille, both father and son served as interpreters to the Royal Legation of Romania for decades. Alphonse Lahaille was the first interpreter of the legation between 1879 and 1908, followed by his son, Joseph.
} 
tra Romana. There are also more famous cases, as for example the journalist, diplomat and possibly spy, Nicolae Bordeano. He was the owner of La Turquie, the author of the book L'Égypte d'après les traités de 1840 - 1841 and a very active Freemason. Another example is the Ashkenazi Jew Sigmund Weinberg, who brought the first gramophone to town, sold supplies for photographers but also organized the first cinema screening in the city in 1896 . He was also the representative of Pathé and opened the first Pathé Cinema. ${ }^{34}$ In 1908, he appears on the list of consulate's subjects. Later, Weinberg became the general manager of the Central Military Office of Cinema/MOFD, Merkez Ordu Film Dairesi, founded by Enver Pasha in Istanbul in 1915 after the German model, as the first national film-making institution, which shot footage on the front in $1916 . \mathrm{He}$ maintained this position until Romania entered the war in August 1916, when he was deported as the subject of an enemy state, and returned to Constantinople only after the war. Until recently he was mentioned in historiography as a Polish subject, so he is just another example of what deeper research can reveal about Romanian-Ottoman relations after 1878.

The pages above constitute the first attempt to reconstruct a Romanian community in the cosmopolitan capital of the Ottoman Empire, a project which confronts different research questions concerning ethno-religious identity as well as the legal ambiguities between the two states. The Romanian authorities in both Bucharest and Istanbul struggled for decades to create a perfect portrait of "the real Romanian subject" in the Ottoman Empire, who respected the legal transformation in both countries. Definitions, categories, interviews, archival research and comparative studies with other consulates were all instruments used by the Romanian consuls to conduct different censuses of the colony. Nevertheless, their presence was visible especially in Pera and Galata, through different businesses or citations in police reports. Further research will bring to light more details about a small community, which was gradually created after the mid- $19^{\text {th }}$ century not only in the imperial capital, but also other port cities.

34 ÇELIKTEMEL-THOMEN 2009: 27-28. 


\section{Bibliography}

Primary sources:

Arhiva Ministerului Afacerilor Externe (AMAE), București, [The Archives of the Romanian Foreign Ministry, Bucharest], Constantinople fonds, folder 422.

Basbakanlık Osmanlı Arsivi (BOA) [The Ottoman Archives of the Prime Minister's Office, Istanbul], Hariciye Nezareti Evrakı. Hukuk Kısmı [fonds Documents of the Ministry of Foreign Affairs. Juridical Problems, hereafter HR.H.], folders 553, 563.

Secondary sources:

BROWN, Philip Marshall. 1914. Foreigners in Turkey. Their Juridical Statues. Princeton Princeton: Princeton University Press.

ÇELIKTEMEL-THOMEN, Özde. 2009. The Curtain of Dreams: Early Cinema in Istanbul, 1896-1923, Budapest: CEU unpublished MA thesis.

DAMEAN, Sorin Liviu. 2011. Carol I si politica externa a Romaniei 1866-1914 [Carol I and the Foreign Policy of Romania 1866-1914]. In Cultura, politica si societate in timpul dominiei lui Carol I. 130 de ani de la proclamarea Regatului Romaniei [Culture, Politics and Society during Carol I' Reign. 130 Years from the Proclamation of the Kingdom of Romania], ed. Gheorghe Cliveti, Adrian-Bogdan Ceobanu, Ionut Nistor, 230-305. Iasi: Demiurg.

DAMEAN, Sorin Liviu. 2017. Carol I. Un monarh devotat [Charles I. A Devoted Monarch]. Targoviste: Cetatea de Scaun.

DAVISON, Roderic.1963. Reform in the Ottoman Empire, Princeton: Princeton University Press.

GIURESCU, Dinu C., DINU, Rudolf \& CONSTANTINIU Laurentiu ed. 2010. Romanian Diplomacy. An Illustrated History, 1862-1947. București: Monitorul Oficial.

IORDACHI, Constantin. 2002. Citizenship, Nation-and State-Building: The Integration of Northern Dobrogea into Romania, 1878-1913. In The Carl Beck; Papers in Russian \& East European Studies 1607: 1-86.

KARPAT, Kemal H. 1983. The Ottoman Population 1830-1914. Demographic and Social Characteristics. Wisconsin: The University of Wisconsin Press

KUNERALP, Sinan \& ÖKTEM, Emre ed. 2012. Chambre des conseillers légistes de la Sublime Porte. Rapports, avis et consultations sur la condition juridique des ressortissants étrangers, le statut des communautés non musulmanes et les relations internationales de l'Empire Ottoman (1864-1912). Istanbul: Les éditions Isis.

KUNERALP, Sinan. 2000. Recueil des traités, conventions, protocoles, arrangements et déclarations signés entre l'Empire Ottoman et les puissances étrangères 1903-1922, vol. 2. Istanbul: The Isis Press.

MURGESCU, Bogdan ed. 2001. Istoria Romaniei in texte [History of Romania in Documents]. Bucharest: Corint.

OSMANAĞAOĞLU, Cihan. 2004. Tanzimat dönemi itibartyla Osmanlı tabiiyyetinin (vatandaşlığının) gelişimi. Istanbul: Legal Yay. 
RACHIERU, Silvana. 2013. A social perspective on the history of modern Romanian diplomacy: the case of the Royal Legation of Romania to Istanbul. In Romanian and European Diplomacy. From Cabinet Diplomacy to the 21st Century Challenges ed. Gheorghe Cliveti, Adrian-Bogdan Ceobanu, Adrian Viţalaru, Ionuţ Nistor, 125-139. Iasi-Trieste: Ed. Universitatii Al. I. Cuza \& Beit Casa Editrice.

RACHIERU, Silvana. 2018. Diplomati si supusi otomani in Vechiul Regat. Relatii otomano-romane 1878-1908 [Ottoman Diplomats and Subjects in the Old Kingdom. Ottoman-Romanian Relations 1878-1908]. Iasi: Ed. Universitatii A1. I. Cuza.

\section{Između kralja i sultana: rumunjska kolonija u Carigradu s kraja 19. stoljeća}

Članak je usredotočen na određene rezultate dugoročnog znanstvenoistraživačkog projekta koji se bavi jednim vrlo konkretnim aspektom rumunjskoosmanskih odnosa nakon 1878. godine, a riječ je o rumunjskim podanicima s prebivalištem u Osmanskom Carstvu, koje su smatrali zajednicom pod zaštitom diplomatskih i konzularnih predstavništava Rumunjske. U ovome članku posebna pozornost posvećuje se definiranju te zajednice i pravnom položaju pripadnika kolonije, registriranih pri rumunjskim konzulatima u imperijalnoj prijestolnici. Analiza uključuje i kratak osvrt na njihovu etno-religijsku strukturu, kao i socioekonomske značajke. Riječ je o prvom pokušaju da se nekoliko aspekata vezanih uz rumunjsku multietničku koloniju u Carigradu analizira s različitih gledišta kao što su zanimanja, isprave o državljanstvu i glavna pitanja koja su utjecala na njihov položaj stranaca s prebivalištem u Osmanskom Carstvu. Primarni izvori podataka su konzularni registri i prepiska između predstavnika rumunjske države i Ministarstva vanjskih poslova, s posebnim naglaskom na analizu neobjavljene zbirke isprava iz Carigradskog fundusa Rumunjskog diplomatskog arhiva. Radi se o zbirci pod br. 422 i naslovom „Registracija“, iz razdoblja 1867-1916. Kako bi se dobila što bolja slika o rumunjskoj koloniji u Carigradu u razdoblju do 1900. godine, korišteni su i drugi izvori poput popisa stanovništva, novina i memoara.

Ključne riječi: strani podanici, Osmansko Carstvo, kolonija, Carigrad, Rumunjska, konzularna konvencija

Key words: foreign subjects, Ottoman Empire, colony, Constantinople, Romania, consular convention

Silvana Rachieru Centre for Turkish Studies

Faculty of History University of Bucharest silvana.rachieru@istorie.unibuc.ro 


\section{FILOZOFSKI FAKULTET SVEUČILIŠTA U ZAGREBU \\ ZAVOD ZA HRVATSKU POVIJEST \\ INSTITUTE OF CROATIAN HISTORY \\ INSTITUT FÜR KROATISCHE GESCHICHTE}

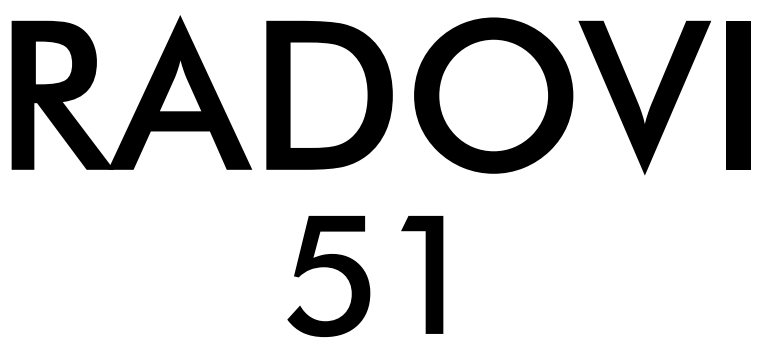

BROJ 1

ZAVOD ZA HRVATSKU POVIJEST

FILOZOFSKOGA FAKULTETA SVEUČILIŠTA U ZAGREBU

\section{FF press}

ZAGREB 2019. 


\section{Poseban broj}

Između Europe i Bliskog istoka: migracije i njihove posljedice na području Jugoistočne Europe $i$

Anadolije u transimperijalnom $i$ interkulturalnom kontekstu

\section{Special issue}

Between Europe and Middle East: Migrations and Their Consequences in Southeast Europe and Anatolia in Transimperial and Intercultural Context 


\title{
RADOVI ZAVODA ZA HRVATSKU POVIJEST FILOZOFSKOGA FAKULTETA SVEUČILIŠTA U ZAGREBU
}

\author{
Knjiga 51, broj 1
}

\author{
Izdavač / Publisher \\ Zavod za hrvatsku povijest \\ Filozofskoga fakulteta Sveučilišta u Zagrebu \\ FF-press \\ Za izdavača / For Publisher \\ Vesna Vlahović Štetić \\ Glavni urednik / Editor-in-Chief \\ Inga Vilogorac Brčić \\ Gostujući urednik / Guest Editor \\ Vjeran Kursar \\ Uredništvo / Editorial Board
}

Jasmina Osterman (stara povijest/ancient history), Trpimir Vedriš (srednji vijek/medieval

history), Hrvoje Petrić (rani novi vijek/early modern history), Željko Holjevac (moderna povijest/

modern history), Tvrtko Jakovina (suvremena povijest/contemporary history), Silvija Pisk

(mikrohistorija i zavičajna povijest/microhistory and local history),

Zrinka Blažević (teorija i metodologija povijesti/theory and methodology of history)

Međunarodno uredničko vijeće / International Editorial Council

Denis Alimov (Sankt Peterburg), Živko Andrijašević (Nikšić), Csaba Békés (Budapest), Rajko

Bratož (Ljubljana), Svetlozar Eldarov (Sofija), Toni Filiposki (Skopje), Aleksandar Fotić

(Beograd), Vladan Gavrilović (Novi Sad), Alojz Ivanišević (Wien),

Egidio Ivetić (Padova), Husnija Kamberović (Sarajevo), Karl Kaser (Graz),

Irina Ognyanova (Sofija), Géza Pálffy (Budapest), Ioan-Aurel Pop (Cluj),

Nade Proeva (Skopje), Alexios Savvides (Kalamata), Vlada Stanković (Beograd),

Ludwig Steindorff (Kiel), Peter Štih (Ljubljana)

Izvršni urednik za tuzemnu i inozemnu razmjenu /

Executive Editor for Publications Exchange

Martin Previšić

Tajnik uredništva / Editorial Board Assistant

Dejan Zadro

Adresa uredništva/Editorial Board address

Zavod za hrvatsku povijest, Filozofski fakultet Zagreb, Ivana Lučića 3, HR-10 000, Zagreb Tel. ++385 (0)1 6120191

Časopis izlazi jedanput godišnje / The Journal is published once a year

Časopis je u digitalnom obliku dostupan na / The Journal in digital form is accessible at

Portal znanstvenih časopisa Republike Hrvatske „Hrčak“ http://hrcak.srce.hr/radovi-zhp

Financijska potpora za tisak časopisa / The Journal is published with the support by Ministarstvo znanosti, obrazovanja i športa Republike Hrvatske

Časopis je indeksiran u sljedećim bazama / The Journal is indexed in the following databases: Directory of Open Access Journals, EBSCO, SCOPUS, ERIH PLUS, Emerging Sources Citation Index - Web of Science 


\title{
Naslovna stranica / Title page by Marko Maraković
}

\section{Grafičko oblikovanje i računalni slog / Graphic design and layout Marko Maraković}

\author{
Lektura / Language editors \\ Samanta Paronić (hrvatski / Croatian) \\ Edward Bosnar (engleski / English)
}

Tisak / Printed by

Tiskara Zelina, Sv. Ivan Zelina

Naklada / Issued

200 primjeraka / 200 copies

Ilustracija na naslovnici

Muza Klio (Alexander S. Murray, Manual of Mythology, London 1898)

Časopis je u digitalnom obliku dostupan na Portalu znanstvenih časopisa Republike Hrvatske ,Hrčak“ http://hrcak.srce.hr/radovi-zhp

The Journal is accessible in digital form at the Hrcak - Portal of scientific journals of Croatia http://hrcak.srce.hr/radovi-zhp 